\title{
Pengaruh Terapi Suportif Keluarga terhadap Kemampuan Keluarga Merawat Klien Gangguan Jiwa di Kecamatan Bogor Timur
}

\author{
Rika Damayanti, Tati Hernawaty \\ Dosen IAIN Raden Intan Lampung dan Dosen Universitas Padjajaran Bandung \\ Diterima: April 2014. Disetujui: Mei 2014. Dipublikasikan: Juni 2014
}

\begin{abstract}
Abstrak: Penyakit jiwa yang dialami oleh 96 orang antara 12.392 jiwa di Kecamatan Bubulak, Bogor Barat. Pada saat bersamaan, pengetahuan dan kemampuan keluarga tidak berjalan baik, pelayanan untuk program kesehatan psikologi oleh Pusat Kesehatan Masyarakat tidak berjalan dengan baik, dan Kelompok Pendukung Keluarga tidak ada. Judul penelitian ini adalah Pengaruh Kelompok Keluarga Pendukung terhadap Kemampuan Keluarga dalam Merawat Klien dengan Penyakit Jiwa di Kabupaten Bubulak, Bogor Barat. Penelitian ini bertujuan untuk mendapatkan gambaran menyeluruh tentang pengaruh Kelompok Pendukung Keluarga terhadap kemampuan keluarga dalam merawat klien dengan penyakit jiwa. Rancangan penelitian menggunakan uji coba pre-post kuasi eksperimental dengan kelompok kontrol dengan menggunakan intervensi Kelompok Pendukung Keluarga. Sampel dipilih dengan menggunakan cluster satu tahap dan terdiri dari 74 keluarga dengan penyakit jiwa klien. Kelompok ini dibagi menjadi 2 kelompok sebagai berikut: Kelompok I (Perawatan kelompok keluarga pendukung, 4 kali pertemuan terdiri dari 2 minggu) dan Kelompok II (tanpa Kelompok Pendukung Keluarga). Kemampuan kognitif keluarga, kemampuan afektif, dan kemampuan psikomotor dinilai dengan menggunakan kuesioner dan kemudian hasil kuesioner dianalisis dengan menggunakan metode dependent-t test, independent ttest, Chi-Square, dan Simple Linear Reggresion. Penelitian ini menunjukkan adanya peningkatan signifikan dalam kemampuan kognitif keluarga, kemampuan afektif, dan kemampuan psikomotor dalam merawat klien dengan penyakit jiwa. Kemampuan kelompok yang ditangani oleh Kelompok Pendukung Keluarga meningkat secara signifikan dan signifikan dibandingkan kelompok tanpa Kelompok Pendukung Keluarga. Dianjurkan untuk membentuk dan untuk melakukan Kelompok Pendukung Keluarga kepada keluarga yang memiliki klien dengan penyakit jiwa di masyarakat.
\end{abstract}

Kata Kunci : terapi suportif, keluarga, gangguan jiwa

\section{Pendahuluan}

Prevalensi gangguan jiwa di Indonesia sangat tinggi. Berdasarkan data Riset Kesehatan Dasar tahun 2007 dinyatakan bahwa prevalensi gangguan jiwa berat secara nasional mencapai 4,6\% dari jumlah penduduk dan prevalensi di propinsi Jawa Barat sebesar 2,2\% (Depkes, 2008) Jumlah ini melebihi batas angka yang ditetapkan WHO bahwa 1-3 per mil penduduk menderita gangguan jiwa (Said, 2008). Pada tahun 2006, penduduk Indonesia sudah mencapai 241.973.900 (Sylva, 2008), maka ada sekitar 11.130.937 penduduk yang mengalami gangguan jiwa berat. Penjelasan di atas menunjukkan bahwa jumlah gangguan jiwa berat sangat tinggi di Indonesia.

Gangguan jiwa adalah respons maladaptif terhadap stressor dari lingkungan internal dan eksternal, dibuktikan melalui pikiran, perasaan dan perilaku yang tidak sesuai dengan norma-norma lokal atau budaya setempat, dan mengganggu fungsi sosial, pekerjaan dan/atau fisik (Townsend, 2005). Pengertian ini menjelaskan bahwa seorang individu akan berespon berupa perilaku menghindar untuk menghindari stimuli yang muncul yang dipersepsikannya sebagai stressor atau hal yang sangat mengancam. Seorang klien gangguan jiwa akan menunjukkan perilaku yang tidak sesuai dengan norma masyarakat pada umumnya karena perilaku tersebut mengganggu fungsi sosialnya.

Menurut Pedoman Penggolongan Diagnosis Gangguan Jiwa III (Saddock \& Saddock, 2007) gangguan jiwa didefinisikan sebagai suatu sindroma psikologi atau pola perilaku yang secara klinis cukup bermakna pada seseorang, dan secara khas berkaitan dengan suatu gejala penderitaan (distress) atau ketidakmampuan dalam satu atau lebih fungsi yang penting dari kehidupan manusia atau peningkatan risiko kematian, nyeri, disability, atau kehilangan yang 
signifikan. Pengertian tersebut memberi penjelasan bahwa gangguan jiwa dapat berupa gangguan jiwa berat atau gangguan jiwa ringan. Klien dengan gangguan jiwa yang berat akan menunjukkan berbagai gejala gangguan psikologis dan ketidakmampuan berfungsi dalam kehidupan sehari-hari (perilaku tidak wajar).

Klien gangguan jiwa akan menunjukkan perilaku yang tidak wajar serta gangguan dalam fungsi sosial. Perilaku yang tidak wajar dapat ditujukan pada perilaku yang tidak ada kesesuaian antara pikiran dan perilaku seperti sedih karena mengalami musibah namun tertawa terbahak-bahak. Gangguan dalam berfungsi secara sosial ditujukan pada ketidakmampuan untuk menjalankan peranan dalam berbagai kedudukan sosial dan yang sesuai dengan tuntutan lingkungannya, serta menunjukkan ketidakmampuan berfungsi secara sosial sebagai manusia. Pada gangguan jiwa ringan, keadaan klien masih berada pada suatu kondisi yang sifatnya berisiko dan mengarah pada keterbatasan untuk melakukan aktifitas sehari-hari secara individu.

Gangguan jiwa disebabkan oleh banyak faktor yang saling mempengaruhi satu sama lain. Beberapa pendekatan yang dominan dikemukakan oleh para ahli dalam menganalisis penyebab terjadinya gangguan jiwa. Berdasarkan The Stuart Stress Adaptation Model, penyebab terjadinya gangguan jiwa adalah faktor predisposisi yang meliputi: biologis, psikologis, dan sosial budaya, serta faktor presipitasi yang meliputi nature, origin, timing, dan number (Stuart \& Laraia, 2006). Sedangkan menurut (Maramis, 2005), penyebab gangguan jiwa meliputi: faktor somatik (somatogenik), psikologik (psikogenik), dan sosial-budaya (sosiogenik). Pandangan lain menyebutkan bahwa penyebab gangguan jiwa ada tiga kategori, yakni faktor individu, faktor interpersonal, dan faktor sosial budaya (Videbeck, 2006). Jadi dari berbagai pendapat di atas, dapat disimpulkan bahwa penyebab gangguan jiwa dapat ditinjau dari faktor biologis, psikologis, dan faktor sosial budaya.

Faktor biologis dapat menyebabkan gangguan jiwa berkaitan dengan adanya gangguan neuroanatomi dan neurokimia yang berkaitan dengan struktur dan fungsi otak, faktor imunovirologik atau respon tubuh terhadap paparan virus (Videbeck, 2006), adanya riwayat keluarga yang menderita psikosis, atau faktor cacat kongenital (Maramis, 2005). Gangguan jiwa diduga terjadi karena terlalu banyaknya penerimaan dopamin dalam otak yang mungkin mempengaruhi gejala-gejala gangguan jiwa atau Skizofrenia. Perubahan aktifitas dopamin mungkin terjadi setelah munculnya psikosis dan bukan sebelumnya (Sutatminingsih, 2002), resiko timbulnya psikosis, termasuk skizofrenia, sekitar empat kali lebih besar pada hubungan keluarga tingkat pertama (saudara kandung, orang tua, anak kandung). Sejauh ini tidak ada bukti yang spesifik atau bukti yang menjanjikan bahwa gangguan jiwa disebabkan oleh genetik meskipun beberapa keterkaitan genetik ditemukan pada gangguan jiwa tertentu (Videbeck, 2006). Tidak ada studi yang benar-benar membuktikan dan menjelaskan bahwa gangguan jiwa disebabkan oleh faktor keturunan, faktor neuroanatomi, atau neurokimia.

Faktor psikologik yang dapat menyebabkan gangguan jiwa berkaitan dengan perkembangan psikologik yang tidak sesuai (Maramis, 2005) atau terjadinya proses fiksasi dalam perkembangan kepribadian. Perkembangan psikologik yang tidak sesuai mungkin disebabkan oleh ketidakmatangan psikis atau kegagalan individu untuk berkembang lebih lanjut ke tahap perkembangan berikutnya. Menurut Havighurst dalam (Hurlock, 1993), jika seseorang berhasil menyelesaikan tugasnya pada periode tertentu maka akan menimbulkan rasa bahagia dan membawa ke arah keberhasilan dalam melaksanakan tugas berikutnya tetapi jika gagal akan menimbulkan rasa tidak bahagia dan kesulitan dalam menghadapi tugas-tugas berikutnya. Setiap individu memiliki tugas perkembangan yang sesuai dengan rentang usianya dimana tugas perkembangan ini memegang peranan penting untuk menentukan arah perkembangan yang normal. Oleh karena itu, adanya hal-hal yang menghalangi pemenuhan tugas perkembangan dapat dianggap sebagai "bahaya" potensial terjadinya gangguan jiwa yang biasanya diawali oleh munculnya penilaian diri yang kurang menyenangkan (Hurlock, 1993). 
Proses fiksasi dalam perkembangan kepribadian dapat terjadi sejak seseorang masih dalam pengasuhan orang tua yang artinya bahwa pola asuh dalam keluarga memberi pengaruh besar terhadap proses terjadinya gangguan jiwa. Sikap orang tua yang kurang bijaksana dalam hal pengasuhan meliputi: melindungi anak secara berlebihan atau karena sikap 'berkuasa' dan 'harus tunduk saja', sikap menolak terhadap anak (anak tidak disukai), menentukan norma etik dan moral yang terlalu tinggi, disiplin yang terlalu keras, dan displin yang tidak teratur atau bertentangan (Yosep, 2007).

Faktor sosial budaya yang dapat menyebabkan gangguan jiwa dapat disebabkan oleh pola keluarga yang terganggu atau pengaruh lingkungan lainnya, sehingga seseorang tidak pernah belajar merespon stimulus sosial secara normal (Sutatminingsih, 2002) atau kondisi lingkungan dalam kehidupan modern seperti sekarang ini yang menjadikan seseorang sulit memperoleh dan mempertahankan identitas diri yang stabil. Dukungan sosial merupakan salah satu sumber koping individu dan dapat berasal dari hubungan antar teman, anggota keluarga, dan bahkan pemberi perawatan kesehatan yang membantu seseorang saat menghadapi masalah (Videbeck, 2006). Individu yang mendapat dukungan dari teman, sahabat, keluarga, dan masyarakat dalam menjalani kehidupannya dan mampu beradaptasi dengan kemajuan jaman yang serba cepat akan dapat bertahan pada saat dirinya mengalami masalah. Gangguan jiwa terjadi pada saat seseorang menghadapi stimulus yang dianggap sebagai stresor yang mengancam dan merasa dirinya tidak mampu mengatasinya bahkan ditambah kondisi dimana tidak adanya dukungan dari lingkungan. Faktor sosial budaya bukanlah penyebab langsung dari timbulnya gangguan jiwa namun berkaitan dengan proses penyesuaian diri seseorang. Data statistik Departemen Kesehatan RI (2000), 70\% dari klien gangguan jiwa berat atau psikotik adalah Skizofrenia dan menurut Maramis (2005) gangguan jiwa berat lainnya selain psikotik adalah depresi berat, ansietas yang berat, dan penyalahgunaan zat yang parah. Besarnya jumlah Skizofrenia pada kasus psikotik dibandingkan gangguan jiwa lainnya dapat memberikan gambaran secara umum tanda dan gejala yang muncul pada gangguan jiwa berat.

Menurut DSM IV (Keliat \& dkk, 2006), tanda dan gejala Skizofrenia meliputi: kehilangan kemampuan penilaian realitas dan penurunan fungsi mental, yang dapat berupa: penurunan atau ketidakmampuan berkomunikasi, gangguan realitas (halusinasi dan waham), gangguan kognitif (tidak mampu berfikir abstrak), afek yang tidak wajar atau tumpul, dan delusi. Di samping itu, terjadi penurunan kemampuan sosial dan fungsi personal, dapat berupa: kesukaran melakukan aktifitas sehari-hari, isolasi sosial, penampilan yang tidak/rapih, lupa melakukan sesuatu, kurang perhatian pada orang lain, sering bertengkar, tidak teratur makan obat, perilaku makan dan tidur yang buruk (Stuart \& Laraia, 2006), tidak mampu bekerja, dan motivasi kurang.

Seseorang dapat dikatakan mengalami gangguan jiwa berat apabila menunjukkan perilaku seperti: ketidakmmapuan merawat diri, tidak mau bersosialisasi, merasa diri tidak berharga, dan/atau menunjukkan afek yang tidak wajar atau tumpul, sehingga menyebabkannya tidak berfungsi secara sosial dalam kehidupan sehari-hari. Hasil survei World Mental Health pada tahun 2000 menjelaskan bahwa psikosis merupakan salah satu gangguan jiwa berat yang cenderung menimbulkan disability (keterbatasan / kekurangan kemampuan) yang berat pada fungsi sehari-hari.

Penanganan klien gangguan jiwa meliputi tiga aspek, yakni biologi, psikologi, dan sosial (bio-psiko-sos). Penanganan secara biologi meliputi pemberian obat dan Electrocardio Therapy (ECT), sedangkan secara psikologis dengan pemberian psikoterapi. Terapi ini dapat diberikan secara langsung pada klien (terapi individu), pada keluarga (terapi keluarga), dan pada kelompok (terapi kelompok). Penanganan secara sosial, berarti adanya upaya pemberdayaan masyarakat. Menurut Menkes RI (2008), kesehatan jiwa harus ditangani oleh pemerintah beserta multi sektor termasuk masyarakat. Keterlibatan masyarakat berkaitan dengan penggunaan sumber daya yang ada di dalamnya. Penggunaan sumber daya yang 
tersedia di masyarakat dapat memberdayakan individu, keluarga, kelompok, dan masyarakat (Keliat, 2003) dalam penelitiannya mengenai sistem dukungan keluarga bagi klien skizofrenia menjelaskan bahwa di dalam melakukan perawatan kesehatan jiwa masyarakat, pendekatan tidak hanya dilakukan pada klien tetapi juga keluarga. Penjelasan di atas menerangkan bahwa dalam menangani klien gangguan jiwa di masyarakat perlu memberdayakan keluarga sebagai salah satu sumber daya yang ada di masyarakat.

Pemberdayaan keluarga serupa dengan pemberdayaan sistem yang berupaya untuk membantu individu (anggota keluarga) untuk mengontrol diri dan mempengaruhi komunitas dalam pemberdayaan individu dan keluarga (sistem dalam komunitas) dengan tujuan meningkatkan pengetahuan, keterampilan, dan kapasitas keluarga agar dapat menjadi pelindung yang handal untuk keluarganya sendiri (Keliat, 2003).

Pemberdayaan keluarga ini ditujukan untuk membangun hubungan yang didasari oleh kesamaan pemahaman dan empati dengan caregivers (pemberi perawatan) dengan berfokus pada kekuatan pemberi perawatan untuk membantu mereka mengidentifikasi sumber daya di masyarakat. Pemberdayaan keluarga ini meliputi upaya untuk: 1) meningkatkan kemampuan keluarga untuk memenuhi pengobatan anggota; 2) membantu keluarga dalam mengurangi disability sosial dan personal anggota; 3) membantu keluarga membangun harapan dan memberi cukup pengaruh dalam lingkungan rumah; dan 4) membantu keluarga dalam meningkatkan kemampuan vokasional klien, memberi dukungan emosi pada pemberi perawatan, dan mengembangkan kelompok swabantu untuk memberi dukungan yang bermanfaat dan membuat jejaring antar keluarga (Murthy, 2003). Jadi salah satu upaya yang dapat dilakukan dalam memberdayakan keluarga dalam rangka memberikan perawatan adalah membantu keluarga dalam meningkatkan kemampuannya merawat klien gangguan jiwa dengan cara memberi dukungan.

Kemampuan memberikan dukungan oleh keluarga dapat ditingkatkan dengan pemberian psikoterapi. Beberapa psikoterapi yang dapat diberikan pada keluarga adalah Psychotherapy Group, Family Therapy, Family Education, Education Group, Self Help Group (Videbeck, 2006), Supportive Group (Rockland, 1993 dalam Stuart, 2001; Teschinsky, 2000 dalam Videbeck, 2006), dan Multiple Family Therapy (Anderson, dkk., 1986 dalam Bedell, dkk., 1997). Dari berbagai psikoterapi yang berguna dalam mengoptimalkan pemberdayaan keluarga dalam merawat klien gangguan jiwa, Supportive Group merupakan alternatif pilihan terapi yang ditujukan untuk meningkatkan kemampuan keluarga menjadi support system. Supportive Group merupakan terapi yang diorganisasikan untuk membantu anggota saling bertukar pengalaman mengenai masalah tertentu agar dapat meningkatkan kopingnya. Support group ditujukan untuk mengurangi beban keluarga dan meningkatkan koping keluarga serta meningkatkan dukungan sosial dan bukan untuk mengurangi frekuensi relaps atau simptom klien (Fadden, 1998, Wituk, dkk.,2000 dalam Chien, dkk., 2006).

Hasil penelitian (Chien, 2006) mengenai efek support group pada keluarga China dengan diagnosa Skizofrenia menunjukkan bahwa Supportive Therapy (TS) memberi efek positif pada beban keluarga, fungsi klien, dan lamanya klien kembali ke RS. Selain itu, memberi dampak pada perilaku keluarga selama 12 bulan lamanya setelah pemberian terapi. Dengan demikian, dapat disimpulkan bahwa pemberian TS memberi keuntungan dalam mengurangi beban keluarga. Keluarga dapat mengidentifikasi dukungan sosial dan menguatkan respon kopingnya yang adaptif dan suportif, meningkatkan kekuatan, dan kemampuan menggunakan sumber-sumber kopingnya (Rockland, 1993 dalam Scott, 1995).

Pemberian Terapi Suportif bagi keluarga (TSK) dapat ditujukan untuk mengoptimalkan pemberdayaan keluarga dalam melaksanakan fungsi perawatan kesehatan anggota keluarga. Fungsi perawatan kesehatan yang dimiliki keluarga merupakan sebuah fungsi yang mendasar, vital, dan berperan sebagai fokus sentral dalam keluarga. Disfungsi salah satu anggota keluarga akan mempengaruhi anggota keluarga lain dan unit keluarga secara keseluruhan. Dengan 
demikian, keluarga harus lebih terlibat dalam tim perawatan kesehatan dan keseluruhan proses terapeutik agar keluarga dapat menjadi sumber pelayanan kesehatan yang efektif dan utama (Friedman, 1998). Kemampuan keluarga yang meningkat dalam merawat anggotanya yang mengalami gangguan jiwa yang berhasil. Pemberdayaan keluarga ditujukan untuk meningkatkan pengetahuan, keterampilan dan kapasitas keluarga agar dapat menjadi pelindung yang handal untuk keluarganya sendiri (Keliat, 2003).

Jumlah pasien gangguan jiwa lebih banyak di masyarakat daripada dirawat di rumah sakit. Di masyarakat, keluarga merupakan pemberi perawatan utama bagi anggota keluarga yang mengalami gangguan jiwa. Kecamatan Bogor Timur sudah ditemukan 96 klien (7,7\%o) gangguan jiwa dari jumlah penduduk 12.392 jiwa, melebihi prevalensi nasional yakni 4,6\%o dari jumlah total penduduk.

Dari hasil wawancara peneliti pada enam keluarga di Kecamatan Bogor Timur pada Bulan Maret 2010, diperoleh data bahwa: keluarga tidak pernah meminta bantuan pada tetangga untuk membantu merawat klien; dua keluarga merasa sulit dan bosan membujuk klien untuk minum obat dan melakukan aktifitas rumah sehari-hari; empat keluarga merasa sendiri dan merasa hanya mereka yang menderita karena memiliki anggota keluarga gangguan jiwa; dan dua keluarga merasa malu karena klien sulit diatur sehingga seringkali dibiarkan karena bingung harus berbuat apa lagi. Dua dari enam keluarga belum pernah membawa anggota keluarganya yang mengalami gangguan jiwa ke Puskesmas. Selama ini keluarga membawa klien berobat ke pengobatan alternatif dan setelah lebih dari satu tahun baru membawanya ke Puskesmas. Berdasarkan data di atas dapat disimpulkan bahwa keluarga merasa bosan merawat, merasa sendiri, merasa malu, pengetahuan dan kemampuan keluarga menggunakan sumber pendukung dalam merawat klien gangguan jiwa masih kurang. Dengan demikian belum mengetahui perlunya dukungan dan informasi cara merawat klien gangguan jiwa. Dari uraian, peneliti ingin mencoba melaksanakan TSK agar keluarga dapat mempunyai sistem pendukung.

\section{Metode Penelitian}

Penelitian ini adalah penelitian quasi expermental dengan metode kuantitatif menggunakan desain "Quasi experimental pre-post test with control group" dengan intervensi terapi suportif keluarga pada tanggal 27 April sampai dengan 14 Mei 2010. Teknik pengambilan sampel dengan cara cluster one stage. Penelitian dilakukan untuk menganalisa perubahan kemampuan keluarga dalam merawat klien gangguan jiwa sebelum dan sesudah terapi suportif keluarga di Kecamatan Bogor Timur dan membandingkan antara kelompok yang mendapatkan terapi suportif keluarga dengan kelompok yang tidak mendapatkan terapi suportif keluarga. Tiap kelompok berjumlah 37 responden. Analisis statistik yang dipergunakan yaitu univariat, bivariat, dan multivariat dengan analisis dependen sample $t$-test, independent sample $t$-test, Chi-square, serta Simple Linear Reggresion dengan tampilan dalam bentuk tabel dan distribusi frekuensi.

\section{Hasil dan Pembahasan}

Penelitian dilakukan di Kecamatan bogor timur terhadap 74 responden (keluarga dengan anggota gangguan jiwa) yaitu 37 responden yang mendapatkan terapi suportif keluarga dan 37 responden yang tidak mendapat terapi suportif keluarga, dengan hasil sebagai berikut:

Hasil analisis dapat disimpulkan pada alpha 5\% adanya peningkatan kemampuan kognitif keluarga yang bermakna antara sebelum dengan sesudah intervensi pemberian terapi suportif keluarga pada kelompok intervensi sebesar 7,16 (p-value <0,05) dan peningkatan yang bermakna pada kelompok kontrol sebesar 2,11 (p-value <0,05). 
Hasil analisis dapat disimpulkan pada alpha $5 \%$ adanya peningkatan kemampuan afektif keluarga yang bermakna antara sebelum dengan sesudah intervensi pemberian terapi suportif keluarga pada kelompok intervensi sebesar 3,57 (p-value $<0,05)$ dan peningkatan yang tidak bermakna pada kelompok kontrol sebesar 0,08 (p-value>0,05). Hasil analisis dapat disimpulkan pada alpha 5\% adanya peningkatan kemampuan psikomotor keluarga yang bermakna antara sebelum dengan sesudah intervensi pemberian terap suportif keluarga pada kelompok intervensi sebesar 13,00 (p-value $<0,05$ ) dan penurunan yang tidak bermakna pada kelompok kontrol sebesar -0,21 (p-value $>0,05$ ).

Hasil uji statistik dapat disimpulkan bahwa pada alpha 5\% rata-rata kemampuan kognitif keluarga dalam merawat klien gangguan jiwa meningkat secara bermakna pada kelompok intervensi lebih tinggi sebesar 4,21, rata-rata kemampuan afektif keluarga dalam merawat klien gangguan jiwa meningkat secara bermakna pada kelompok intervensi lebih tinggi sebesar 3,92, dan rata- rata kemampuan psikomotor keluarga dalam merawat klien gangguan jiwa meningkat secara bermakna pada kelompok intervensi lebih tinggi sebesar $14,10$ (p-value $<0,05)$.

Berdasarkan hasil uji statistik dapat disimpulkan bahwa pada alpha 5\% tidak ada kontribusi karakteristik keluarga (usia, hubungan keluarga, pendidikan, pekerjaan, dan pendapatan) terhadap kemampuan kognitif, afektif, dan psikomotor keluarga (p-value >0,05).

Keseluruhan hasil analisa diatas terangkum dalam tabel 1 sampai dengan tabel 3.

Tabel 1. Analisis Kesetaraan Karakteristik Usia, Hubungan Keluarga,

Pendidikan, Pekerjaan, dan Pendapatan Antara Kelompok Intervensi dengan Kelompok Kontrol Di Kecamatan Bogor Timur Bulan April- Mei 2010

\begin{tabular}{|c|c|c|c|c|c|c|c|c|}
\hline \multirow{2}{*}{\multicolumn{2}{|c|}{ Variabel }} & \multicolumn{2}{|c|}{ Intervensi } & \multicolumn{2}{|c|}{ Kontrol } & \multicolumn{2}{|c|}{ Total } & \multirow{2}{*}{$\begin{array}{c}\mathbf{P} \\
\text { value }\end{array}$} \\
\hline & & $\mathrm{N}$ & $\%$ & $\mathrm{~N}$ & $\%$ & $\mathrm{n}$ & $\%$ & \\
\hline \multirow{2}{*}{ Usia } & & & & & & 37 & 50 & 0,239 \\
\hline & & & & & & 37 & 50 & \\
\hline \multirow{2}{*}{ Hub Klg } & Ibu & 29 & 39.2 & 29 & 39.2 & 58 & 78.4 & \multirow{2}{*}{1.000} \\
\hline & Klg lain & 8 & 10.8 & 8 & 10.8 & 15 & 21.6 & \\
\hline \multirow{2}{*}{ Pendidikan } & Dasar & 26 & 35.1 & 26 & 35.1 & 55 & 74.3 & \multirow{2}{*}{0.595} \\
\hline & Menengah & 11 & 14.9 & 11 & 14.9 & 19 & 25.7 & \\
\hline \multirow{2}{*}{ Pekerjaan } & Bekerja & 31 & 41.9 & 31 & 41.9 & 62 & 83.8 & \multirow{2}{*}{1.000} \\
\hline & Tdk bekerja & 6 & 8.1 & 6 & 8.1 & 12 & 16.2 & \\
\hline \multirow{2}{*}{ Pendapatan } & $\begin{array}{l}\text { Di bawah } \\
\text { UMK }\end{array}$ & 32 & 43.2 & 32 & 43.2 & 65 & 87.8 & \multirow[t]{2}{*}{1.000} \\
\hline & Diatas UMK & 5 & 6.8 & 5 & 6.8 & 9 & 12.2 & \\
\hline
\end{tabular}

Tabel 2. Analisis Kesetaraan Kemampuan Sebelum Pelaksanaan Terapi Suportif Keluarga Di Kecamatan Bogor Timur Bulan April-Mei 2010

\begin{tabular}{cccccc}
\hline Kemampuan & Kelompok & Mean & SD & t & $\begin{array}{c}\text { P- } \\
\text { value }\end{array}$ \\
\hline \multirow{2}{*}{ Kognitif } & Intervensi & 38.73 & 3.920 & \multirow{2}{*}{1.059} & 0.293 \\
\cline { 2 - 5 } & Kontrol & 39.57 & 2.794 & & \\
\hline \multirow{2}{*}{ Afektf } & Intervensi & 40.11 & 5.532 & - & \multirow{2}{*}{0.479} \\
\cline { 2 - 5 } & Kontrol & 39.16 & 5.890 & 0,712 & \\
\hline \multirow{2}{*}{ Psikomotor } & Intervensi & 33.05 & 6.472 & - & \multirow{2}{*}{0.436} \\
\cline { 2 - 4 } & Kontrol & 32.05 & 4.301 & 0,783 & \\
\hline
\end{tabular}

Tabel 3. Analisis Perbedaan Peningkatan Kemampuan Keluarga Antara Kelompok Intervensi dan Kelompok Kontrol Di Kecamatan Bogor Timur Bulan April-Mei 2010

\begin{tabular}{cccc}
\hline Kemampuan & Kelompok & Selisih & P-value \\
\hline \multirow{2}{*}{ Kognitif } & Intervensi & 7.16 & \multirow{2}{*}{0.000} \\
\cline { 2 - 3 } & Kontrol & 2.11 & \\
\hline
\end{tabular}




\begin{tabular}{cccc}
\multirow{2}{*}{ Afektf } & Intervensi & 3.57 & \multirow{2}{*}{0.479} \\
\cline { 2 - 3 } & Kontrol & 0.08 & \\
\hline \multirow{2}{*}{ Psikomotor } & Intervensi & 13.00 & \multirow{2}{*}{0.436} \\
\cline { 2 - 3 } & Kontrol & $-0,21$ & \\
\hline
\end{tabular}

Kemampuan keluarga dalam penelitian ini adalah kemampuan kognitif, afektif, dan psikomotor. Hasil penelitian menunjukkan bahwa sebelum dilakukan intervensi TSK, rata-rata kemampuan kognitif pada kelompok keluarga yang mendapat TSK sebesar 38,73 sedangkan kelompok keluarga yang tidak mendapat TSK sebesar 39,57, rata-rata kemampuan afektif baik pada kelompok keluarga yang mendapat TSK sebesar 40,11 sedangkan kelompok keluarga yang tidak mendapat TSK sebesar 39,68, dan rata-rata kemampuan psikomotor pada kelompok keluarga yang mendapat TSK sebesar 33,05 sedangkan kelompok keluarga yang tidak mendapat TSK sebesar 32,16.

Kemampuan kognitif dan psikomotor baik pada kelompok yang mendapat TSK dan yang tidak mendapat TSK berada pada kategori cukup karena berada pada rentang 30,5-45. Kedua skor kemampuan ini masih berada di bawah skor minimal kategori baik (skor minimal kemampuan kognitif $=45,5)$. Skor kemampuan kognitif sebelum pemberian TSK $(38,73)$ masih memerlukan peningkatan sebesar 6,77 agar dapat mencapai skor minimal kategori baik. Peningkatan ini diharapkan dapat terwujud dengan pemberian TSK karena di dalam TSK terdapat aspek psikoedukasi yang ditujukan untuk meningkatkan kemampuan kognitif keluarga mengenai penggunaan sumber pendukung.

Harapan pencapaian peningkatan kemampuan kognitif diharapkan melebihi peningkatan yang terjadi pada kelompok kontrol yang meningkat sebesar 2,11. Berarti seiring berjalannya waktu, tanpa pemberian TSK pun kemampuan kognitif keluarga tetap dapat meningkat mencapai kategori baik. Prediksi ini bertentangan dengan pendapat Salthouse (2010) yang menjelaskan bahwa kognitif seseorang mulai menurun ketika mereka berada di usia 20-an dan 30-an karena proporsi terbesar responden pada kedua kelompok berada pada rentang usia dewasa pertengahan (40 tahunan).

Meskipun kondisi ini tidak sejalan dengan hasil riset yang dilakukan oleh Buckley, dkk. (2008) mengenai TS untuk Skizofrenia bahwa tidak banyak perbedaan yang ditemukan antara pemberian TS dengan terapi lainnya. Hasil penelitian menunjukkan bahwa sebelum dilakukan intervensi TSK, rata-rata kemampuan afektif baik pada kelompok keluarga yang mendapat TSK $(40,11)$ maupun kelompok keluarga yang tidak mendapat TSK $(39,68)$ berada pada kategori kurang mendukung karena berada di bawah nilai median (nilai median kemampuan afektif $=40,5)$.

Skor kemampuan afektif kelompok keluarga yang mendapat TSK $(40,11)$ masih memerlukan peningkatan sebesar 0,39 agar dapat mencapai skor minimal kategori mendukung. Peningkatan ini diharapkan dapat terwujud dengan pemberian TSK karena di dalam pemberiannya terdapat aspek afektif seperti cara keluarga harus saling berempati satu sama lain, memperhatikan tetangga di sekitar bila ada anggotanya yang mengalami gangguan jiwa, dan memberi dukungan selama pelaksanaan terapi bahkan di luar sesi TSK.

Harapan pencapaian peningkatan kemampuan afektif diharapkan melebihi peningkatan yang terjadi pada kelompok kontrol yang meningkat sebesar 0,08. Berarti tanpa pemberian TSK pun kemampuan afektif keluarga tetap dapat meningkat mencapai kategori baik meskipun dalam rentang waktu yang lama.

Kemampuan afektif yang masih termasuk kategori kurang mendukung kemungkinan karena kemampuan ini berkaitan dengan kemampuan kognitif. Menurut Asch (1952, dalam Anonim, 2010) menjelaskan bahwa semua sikap bersumber pada organisasi kognitif, pada informasi dan pengetahuan yang dimiliki. Dengan demikian, kemampuan afektif yang kurang mendukung diharapkan dapat meningkat seiring dengan meningkatnya kemampuan kognitif 
kelaurga dalam merawat klien gangguan jiwa. Namun mungkin saja peningkatan kemampuan afektif ini tidak sesuai dengan harapan mengingat proporsi pendidikan rendah pada kedua kelompok sangat besar $(39,2 \%)$.

Hasil penelitian menunjukkan bahwa sebelum dilakukan intervensi TSK, rata-rata kemampuan psikomotor baik pada kelompok keluarga yang mendapat TSK $(33,05)$ maupun kelompok keluarga yang tidak mendapat TSK $(32,16)$ berada pada kategori cukup karena berada pada rentang 30,5-45. Kedua skor kemampuan ini masih berada di bawah skor minimal kategori baik (skor minimal kemampuan psikomotor $=45,5$ ).

Skor kemampuan psikomotor kelompok keluarga yang mendapat TSK $(33,05)$ masih memerlukan peningkatan sebesar 12,45 agar dapat mencapai skor minimal kategori baik. Peningkatan ini diharapkan dapat terwujud dengan pemberian TSK karena di dalam TSK terdapat aspek yang dapat meningkatkan kemampuan psikomotor seperti adanya role paly menggunakan sumber pendukung, adanya demonstrasi, bahkan terdapat buku kerja yang selalu diisi dengan catatan perkembangan kemampuan keluarga di setiap sesinya.

Harapan pencapaian peningkatan kemampuan psikomotor diharapkan melebihi kemampuan keluarga pada kelompok kontrol yang justru mengalami penurunan sebesar - 0,21. Berarti seiring berjalannya waktu, tanpa pemberian TSK, kemampuan psikomotor keluarga akan mengalami penurunan. Tentu saja hal ini sangat memprihatinkan mengingat penurunan ini dapat menyebabkan kemampuan psikomotor keluarga mencapai skor 0 .

\section{Simpulan dan Saran}

Karakteristik anggota keluarga (care giver) yang terlibat dalam penelitian di Kecamatan Bogor Timur ini paling banyak berada dalam rentang usia dewasa madya, mempunyai hubungan keluarga sebagai ibu, memiliki tingkat pendidikan dasar, berstatus tidak bekerja, dan memiliki pendapatan di bawah Upah Minimum Kota.

Kemampuan keluarga di Kecamatan Bogor Timur dalam merawat klien gangguan jiwa sebelum dilakukan intervensi memiliki: kemampuan kognitif berada dalam kategori cukup, kemampuan afektif berada dalam kategori tidak mendukung, dan kemampuan psikomotor berada dalam kategori cukup. Terapi Suportif Keluarga yang diberikan kepada keluarga yang mempunyai anggota gangguan jiwa di Kecamatan Bogor Timur dapat meningkatkan kemampuan kognitif, afektif, dan psikomotor secara bermakna. Keluarga yang tidak mendapat Terapi Suportif Keluarga, kemampuan kognitifnya meningkat secara bermakna, kemampuan afektifnya meningkat namun tidak bermakna, dan kemampuan psikomotornya menurun secara tidak bermakna. Kemampuan kognitif, afektif, dan psikomotor pada kelompok keluarga yang mendapat Terapi Suportif Keluarga lebih tinggi secara bermakna dari kelompok keluarga yang tidak mendapat Terapi Suportif Keluarga. Kemampuan keluarga merawat klien gangguan jiwa baik secara kognitif, afektif, dan psikomotor tidak dipengaruhi oleh karakteristik keluarga.

\section{Daftar Pustaka}

Abdul Aziz, H. (2011). Pendidikan Karakter Berpusat pada Hati. Jakarta: Al-Mawardi.

Chien, W. C. (2006, April 9). Effects of a Mutual Support Group for Families of Chinese People With Schizophrenia: 18-Months Follow-Up. Retrieved from http://bjp.rcpsych.org

Depkes , R. (2008). Riset Kesehatan Dasar 2007. Jakarta: Badan Penelitian dan Pengembangan Kesehatan Republik Indonesia.

Elizabeth, W. (1999). Coping with Sress. Retrieved from Coping with Sress: http//:www.Psycologi.Com

Friedman, M. M. (1998). Keperawatan Keluarga: Teori dan Praktek. Alih bahasa: Ina Debora R.L, dkk. Ed.3. Jakarta: EGC. 
Ginanjar, G. A. (2007). Rahasia Sukses Membangun Kecerdasan Emosi dan Spiritual: ESQ. Jakarta: Arga.

Hurlock, E. (1993). Psikologi Perkembangan. Jakarta: Penerbit Airlangga.

Keliat. (2003). Disertasi. Pemberdayaan Klien dan Keluarga Dalam Perawatan Klien Skizofrenia dengan Perilaku Kekerasan di Rumah Sakit Jiwa Pusat Bogor. Jakarta.

Keliat, B., \& dkk. (2006). Modul Model Praktek Keperawatan Profesional Jiwa (MPKP) Jiwa. Jakarta: WHO-FIK UI.

Kozier. (1999). Fundamental of Nursing Concepts Procces and Practice. Addison Wesley Publishing Company Inc.

Lengua, J., \& Stomrmshak. (2000). Gender Roles and Personality. Retrieved from Gender: http//:www.findarticle.com

Lickona, T. (1992). Educating for Character, How Our Schools Can Teach Respect and Responsibility. New York: Bantam Books.

Lickona, T. S. (2003). CEP's Eleven Principles of Effective Character Education. Washington, DC: Character Education Partnership.

Maramis, W. (2005). Catatan Ilmu Kedokteran Jiwa. Cetakan 9. Surabaya: Airlangga University Press.

Murthy. (2003, 9 Januari). Family Interventions and Empowerment as An Approach to Enhance Mental Health Resources in Developing Countries. . Retrieved from pubmedcentral: http://www.pubmedcentral.nih.gov

Niven, N. (2000). Psikologi Kesehatan Pengantar untuk Perawat dan Profesi Kesehatan lain. Jakarta: EGC.

Philips, S. U. (2001). Participant structures and communicative competence: Warm Springs children in community and classroom.

Saddock, B., \& Saddock, V. (2007). Kaplan and Saddock's Synopsis of Psychiatry: Behavioral Science/Clinical Psychiatry. 10th. Ed Lippincott William \& Wilkins.

Said. (2008). Hidup Makin Sulit, Gangguan Jiwa Mengintip.

Smet, B. (1994). Psikologi Kesehatan. Jakarta: Grasindo.

Stuart, G., \& Laraia. (2006). Principles and Practice of Psyhiatric Nursing. (7th ed). St. Louis: Mosby Year.

Stuart, G., \& Laraia, M. (1998). Principles and Practices of Psyciatric Nursing. St Lois: Mosby Inc.

Sutatminingsih, R. (2002, Januari 9). Schizophrenia. Retrieved from Schizophrenia: http://www.library.usu.ac.id/modules.php

Sylva. (2008, Januari 9). Indonesiaku. Retrieved from Indonesiaku: http://www.worldatlas.com

Taylor, C. L., \& C. Le Mone.P. (1997). Fundamental of Nursing Care. Lippincott: Raven Publishers.

Townsend, C. (2005). Essentials of Psychiatric Mental Health Nursing. (3th Ed.). Philadelphia: F.A. Davis Company.

Videbeck, S. (2006). Psychiatric Mental Health Nursing. (3rd Ed). Philadhelpia: Lippincott Williams \& Wilkins.

Yosep, I. (2007). Keperawatan Jiwa. Cetakan pertama. . Bandung: PT.Refika Aditama.

Yusuf, S. (2004). Mental Hygiene Pengembangan Kesehatan Mental dalam Kajian Psikologi dan Agama,. Jakarta: Pustaka Bani Quraisy. 